\author{
Olesia SMOlinska \\ Lviv Stepan Gzhytskyi National University of Veterinary Medicine and Biotechnologies \\ https://orcid.org/0000-0003-1612-2830 \\ Khrystyna DZyubyNSKa \\ Lviv Stepan Gzhytskyi National University of Veterinary Medicine and Biotechnologies \\ https://orcid.org/0000-0001-8413-6017
}

\title{
IDENTIFICATION PROCESSES IN CULTURAL AND EDUCATIONAL SPACE OF THE UNIVERSITY AS A SOURCE OF THE NASCENCE OF EDUCATIONAL VALUES
}

\begin{abstract}
Values, especially educational, are produced institutionally. That is why the study of their content without analyzing the origin and methods of generating leads to fragmentary research. University, in fact, is this public institution in the cultural and educational space, where the values of higher education that correspond to current political and economic status of society and have historical and cultural nature, are formed, circulate, develop and freeze. The process of generating values is simultaneous with the process of identification, thus, different groups of values, differences in identification should be taken into account and, particularly those typical of the university, which define its characteristics, including self characteristics. They include temporal, physical/body, social-class self-identity; however, beyond the scientific analysis, there are gender, national and other kinds, although they are no less significant to the Ukrainian reality. An important conclusion is that that there is a causal relationship between the self-identity of the university and origin and evolution of educational values in its cultural and educational space that prove the influence of university education on the development of society, in particular - as regards putting forward priorities and forming goals.
\end{abstract}

Keywords: university, cultural and educational space, identification, self identification, values

Humanities, in addition to discovering and structuring of scientific facts, pay great attention to the issue of values that determine the general concept of the individual. The formation of values is the task of social institutions, one of them is education and its institutions, including universities. 
Terminology is related to the issue of identity and has recently become widely popular in various sciences: pedagogy, sociology, psychology, political science, cultural studies. However, the problem of identity is rather ambiguous, as it includes a number of elements that are on the edge of personal and public, the proportion of which varies depending on the social-historical period. A classical approach implies considering it from the standpoint of separation of "self" and its emancipation as to the environment, and the "self" often had the individual nature. Works on such an issue are psychological and sociological investigations, which study the formation of individual concepts in the process of personal identification through interpersonal interactions. Modern scientific literature identifies various approaches, including a shift to the exploration not of an individual but of collective identity (students of the university, teachers as a professional group, however, it is said more about professional adaptation, etc.); besides, approaches according to which an identity is the result of certain discourse (educational, cultural, social, etc.) are initiated, thus, it goes beyond the scope of purely active-technological approaches. The appearance of parallel, virtual reality through the development of new information technologies and new means of communication, has caused the emergence of virtual identities of various types, the correlation with which is also interpreted by modern authors as identification, and is also actualized concerning a university pedagogical education, mainly in the sphere of media pedagogy. Finally, identity is mainly interpreted as the reserve involvement of core forces (in the context of this study - values), rather than their product.

\section{THE CONTENT OF IDENTIFICATION IN THE CULTURAL AND EDUCATIONAL SPACE OF UNIVERSITY}

The end of the $20^{\text {th }}$ century is characterized by progressing of globalization, erasing the borders of states and nations in the informational unity of the world. It also excels by the activation of the process of isolating the single from the general both in personal and institutional (organizational) terms, updating notions of identity, self-identity (E. Erikson) and related crises - turning points between progress and regress. The issue of professional identification is not new, but its organizational context is often ignored by the local researchers as the possibility of existence of non-institutional identity in education has been recently recognized. Discussing the issues of identification processes, progressing from the point of view of collective identification, was interesting for sociologists, whereas from the point of view of individual identification - for psychologists, except for the stratametrical concept of A. Petrovskiy, according to which, the third layer of interpersonal relations 
in a group is actually active relations (manifestation of cultural and educational space) with the subject of the activity, where the most important is mastering of the social meaning of the activity itself (Petrovskiy 1982).

Taking into account the complexity of individual identity that takes place in an informational and virtual oversaturation (hence the predominance of mass culture, pluralistic morality), it should be noted the increasing role of the university of postmodern period as a part which is involved in the development of the individual (E. Erikson). When exploring the problem of identity, and the problem of his/her way of identification, researchers usually perceive his/her surrounding as an unstructured fact, ignoring the ability to self-develop, as this comparison is very complicated by the emergence of countless criteria, which, in addition, are very dynamic. It all shows the necessity for an identification processes research in the integrated space of culture and education of the university. When exploring the identification process in terms of cultural and educational space of the university, it is not so important to distinguish stages of this process (they are the same as in the aspect of personality), but to outline the basic structures as to the identification and its type - self-identification. We accept the structure of identification proposed by M. Kozlovets and I. Zakharchenko who perceive identity as the part of the overall composition of identity and reference structures, as

(...) really existing (or imaginary) community that a person compares himself with, refers himself to and the norms and values by which he is guided in his behavior and self-esteem. They are the source of the norms of behavior, social attitudes and values of human, a standard with the help of which an individual evaluates himself and others (Kozlovets, Zakharchenko 2001, p. 21).

Thus, the patterns of cultural and educational space, concerning the personality and its identity (professional, ethnic, civil, social, class belonging, etc.) realize the function of reference structures and, at the same time, change into identities concerning general life circumstances of the university of the same types (professional and others) and as the result we are able to define different kinds of identification. That is why the personal self-identity at the university is closely connected with professional, mental, qualitative characteristics, the ways, whose mechanisms are often determined by the existing partners in the cultural and educational space that serve as a certain guide for the personality and are accepted and adopted by him/her as successful ones. 


\section{SELF-IDENTITY OF THE UNIVERSITY}

The issue of self-identity of the university is a component of the general process of its identity formation, which covers not only the depiction of the inner space, but also the process of image formation, brand development (as the answer to the time requests). Globalization, defined by a number of researchers as the means of a self-identity in cultural and national sense, catalyzes other identification processes, especially in the system of education that is "transmitting membrane" of the whole body of a state/nation, assigning them [identification processes] a cultural and educational character. The identity crisis of universities (Sosvun 2011), which is caused by a number of political, economic and social changes is deepened not only because of external factors, but mostly is connected with the power and effectiveness of internal factors. In addition, a factor that stimulates the identification process is the autonomy of universities when the university's "self" turns into negative, in fact becomes isolated, without strong ties built on the basis of similarities or differences. As regards the man, it can cause the increased risk of depression, self-destructive behavior and so on. When it comes to the university, all these manifestations also exist, although are modified, and occasionally result in various protests, corruption scandals, which are solved mostly with the help of administration that leads to further aggravation of the accumulated problems, which require patient, persistent, systematic and continuous work of all the staff, which is aimed at the formation of mutually harmonious relations between the individual and collective identity in their relation to the profession. To study the processes of identification, we follow the thesis of L. Drobizheva about their innovative nature, which is firstly connected with the active subjectivity, and secondly, with dynamic character. Using the author's statement about the society regarding the university as one of its institutions,

(...) $[t]$ his is the space of identities that is constantly changing. If until recently a change of identity has covered marginalization, in today's world, the risk to become marginalized is higher in those who keep the identity despite the change of an objective social situation and who is not able to accept new social realities (Drobizheva 2007, p. 9).

We conclude that the presence of subsystems of identification in cultural and educational space of university is a specific regulator of its effectiveness, and too much force of formed patterns can lead to self-destruction and dysfunctionality of the investigated sphere in general.

Especially the research on identity becomes active during the periods of reforms, because this structure is closely related to any transformations or modifications. 
The significance of the problems of subsystem identification in functionality of cultural and educational space of university is complicated due to the fact that, despite the low autonomy, some types of identity of Ukrainian universities have already been formed for the last 20 years and the strengthening of autonomy, which is envisaged by the new law "On Higher Education", at the beginning will certainly lead to rapid growth in the scale features, and increased negative identity (We are the treasure of all the values and they are those who destroy them, so they are threat to us (O. Hnatiuk). As a result, own tradition is usually honored and praised, whereas other traditions are met with a hostile attitude (E. Sayid). The paradox is that the own image arises in the alien one. And vice versa, the alien image is based on our own image (D. Lanhevishe). Therefore, the image of the enemy itself promotes a formation of the common identity (N. Lumann) (M. Shulga)), which will have two possible options for solving: the further development of universities capable of adopting a new type of identity; marginalization and decline of those among them, which, thanks to their powerful qualities of cultural and educational spaces have resisted a change.

In spite of the fact that the result of self-identity is a defined identity, the importance of inner disposition of the university is often lost (Stepin 2004; Turkot 2011; Perminova 2004). The processes, which take place at Ukrainian universities, indicate a number of problems of identifying nature, namely:

- the problem of determining the age of universities, organizational time;

- the problem of perception of universities' formed internal and external features;

- the problem of integral formation of the university's image.

The analysis of the above-mentioned problems is possible, using the psychodynamic-anthropological approach to the study of cultural and educational space of the university, i.e. studying the inner world of an organization, as a human being, focusing on the same individually and socially stipulated properties, phenomena, processes, features.

\section{TIME (“AGE”) SELF-IDENTITY}

The age factor is really crucial in the analysis of the process of human development, from the standpoint of psychology. In the adolescence the issue of time of change is particularly acute because it determines the perception of reality by an individual, who actualizes himself. Studying the age and temporal unity of the life of university, similarly to a man, objective criteria and conscious age should be taken into account. The problem of objective age of the university and its in- 
ternal "I" (cultural and educational space) reveals the dichotomy of "youth-old age" at the plane of time and experience. If you perceive a university, for example a pedagogical one, as a bureaucratic organization, then its human age corresponds to the initial period of early adulthood; if we consider the fact that they [pedagogical universities] appeared on the basis of educational institutes, then such a university moves from adulthood to the old age; but judging from the institutional parameters of time, they are the old and young organizations at the same time. Therefore, the real age is not so important, but its inner-organizational sensation is something that really matters, moreover, fuzziness of performance criteria of the organization tends to "deepen" its own history (Hartman 2003, p. 64), which is then represented as one of the merits, the sign of efficiency. As educational institutions, Ukrainian universities cannot be perceived as young, although, in fact, they are, in addition, each university, creating its own biography, tries to deepen it in time. The external effect arising from it, bears the distorted impression that the university, based on tradition (mainly national, as state has not strengthened in Ukraine), is able to create "rightly educated" professionals. This marketing strategy is often used by modern universities. The internal effect of this "aging" is not so obvious; moreover, its sense is somewhat different: temporal transpective of cultural and educational space shifts towards the past, that is why the selfidentity of the university is made by the old and fixed patterns, which are often exhausted. Thus, there is a specific relationship between the past and the future, which, first of all, excludes the current moment, which is not worth to focus on, and, especially, to identify yourself with, because this is just a moment and identification is a process; secondly, the future refers to the past, abolishing the need for development, creating the visibility of cultural completeness, perfection. This is exactly what led modern universities to the need for not only external but also internal changes, the identifying contents of which is to distinguish between the past and the future, understanding the organizational time as the current problem which can be expressed by the metaphor of The Picture of Dorian Gray where the time of an image does not match the temporal nature and in times of crisis can lead to destruction (of the organization-university, its culture, social relations).

\section{“PHYSICAL/BODY” SELF-IDENTITY}

The so-called "physical/body" identity is certainly noteworthy in the aspect of self identification - this is the process of acquiring individuality by reproducing one's own body image in relation to anthropological-cultural models (Semenova 2004). The difficulty in determining the meaning of "physical" identification 
of universities is primarily in terms of the concept of body: studying buildings, classrooms, bases (practice, recreation) or faculties, institutes, departments, colleges, scientific research, industrial structures and so on. In our opinion, physical/body approach can be both applied in the material (training base) and structural (subdivisions) contexts. Describing the physical/body self-identity of the university, it is worth determining the common features of similar processes in humans. First of all, the university does not appear from anything. These are material resources that are controlled by authorities as well as students, especially applicants, who also constitute the university's corporeal identity. Secondly, the mechanism of physical self-identity is similar to the human one and consists in correlation and coexistence of meanings "the image of my body to me" and "the image of my body to others". It means that, depending on the locus of control, it is characteristic of this image to have higher or lower dependence on external factors. Ukrainian universities, though showing quite significant dependence on the environment (the same supervisory institutions, students and their parents, employers), at the same time evaluating the attractiveness of their own image, rely more on inner judges, that is reflected in persistent efforts to resist the deserved criticism for outdated equipment, technical content of the educational process, justifying it by their poor funding and not sufficient conditions. This duality may be due to the influence of the following factors: personal (the presence of a leader-manager, successful manager, which is problematic because not always a rector-scientist is able to be an effective manager), mental (formulas "when in Rome do as the Romans do" or "the hunchback only sees the hump of his neighbor" act as an internal denying of any possibility of an external evaluation of the established order in an organized cultural and educational space, especially because, historically, the medieval universities had a separate law and did not subject to the city's law), cultural and organizational (universities are slowly changing their faces, the majority of employees, students and graduates get used to them, and, therefore, they perceive it through the prism of their attitude to culture, rather than appearance), institutional (conservatism of the essence of education and training, the so-called tradition, stipulates the conservatism of the university physical/body perception). An interesting example of a successful physical self-identity of the university, which is unique in the history of Ukrainian university education, was the fact of revival of National University of Kyiv-Mohyla Academy in 1991, after a 174-year break in its activity. Now it is one of the most prestigious universities. Recalling the events that took place more than 20 years ago, the rector-organizer - now the Honorary President of the University, V. Brukhovetskyy - said that the renewal of the activity in its "body" was crucial and mentioned "the revival of Kyiv-Mohyla Academy on its historical territory as an independent higher institution of education 
in Ukraine", although the then President of Ukraine - Leonid Kravchuk - made a very generous proposal to position the university on the premises of the former Republican Higher Party School, which was rejected exactly because of the next physical identification of the university.

(...) When you come into the Congregational hall and you know that Skovoroda sang there, as well as Berezovskyi and Vedel were there - well, these walls remember them, those sounds (...). And we think that they do not remember but the vibration of these sound leaves its cracks, and they are there (Brukhovetskyy 2013).

Modern technologies, bringing the concept of virtual body, have a negative influence on physical self-identity of a human being, fragmenting it and specifying narcissism, replacing real life with role-play situations that lead to conformity or, on the contrary, to the negative non-conformity and, gradually, deprive the subject of an opportunity to make decisions through unrestricted branching of an appropriate "decision tree". In fact, the same situation exists in the cultural and educational space of the university where virtual, existing as a project/vision of the university, and the true reality divided its bodily identity according to the principle "to be - to seem". This is an obvious sign of the university identity crisis that is prior to the next stage of its development: deliberate combination of these realities means progress, their alienation - regress of the university as an organization, crushing of its key patterns in the cultural and educational space.

\section{SOCIAL CLASS SELF-IDENTITY}

In the light of current social changes, again (after the national identification processes, which were the result of the collapse of the USSR) the tendency concerning the social and class identification appeared, which differed from the Soviet one by less distinct divisions between social classes, their number, change of methodological approaches to their differentiation, enrichment of sociological tools. One of the means of social class identification is the self-identity of the person, the essence of which lies in referring yourself to a certain class. As a result, a person truly becomes its member. However, according to E. Wright (1978), professional activity is not as important as the presence of management functions, certain autonomy and level of qualification, while the current class hierarchy is insensitive to the nature of work (both physical and intellectual), or to sectors of economy, where it [work] materializes (Simonchuk 2007). All this will direct the researcher to the initial source of such social sectors formation as a university, because, according to G. Caffentzis and G. Federici, 
(...) as was the factory, so now is the university. Where once the factory was a paradigmatic site of struggle between workers and capitalists, so now the university is a key space of conflict, where the ownership of knowledge, the reproduction of the labour force, and the creation of social and cultural stratifications are all at stake. This is to say the university is not just another institution subject to sovereign and governmental controls, but a crucial site in which wider social struggles are won and lost (Caffentzis, Federici 2007).

Thus, the transition to a post-industrial era (for universities - in the post-modern stage of development) is also marked by the emergence of a new "battlefield" for social equality, which became a university education. Consequently, social class identification takes place in the cultural and educational space of the university, as the society receives a powerful social class with definite, formed characteristics (they are now called competences).

Extremely important and complex result of education, including university, is the formation of social strata (sociologists generally divide them into 4 types: slavery, caste, state, classes). The most dynamic of these are classes, where transitions are determined by personal efforts of an individual and are aimed at overcoming social barriers, not his/her social origin. Hence, the role of universities is similar to that of "social elevators" that are designed to pave the way for the individual's development as regards his/her social position. However, it is not only Ukraine and the former Soviet Union countries, but also other educational systems in which university education does not only realize this function but, on the contrary, it creates conditions for securing (by law or custom) certain rights and responsibilities, where the transition from one social stratum to another is very difficult, almost impossible. The reasons for this inequality are different (for example, for Ukrainian higher education - destruction of the system of the 1990s, whereas for foreign universities - tough competition between public and private education), but there is one source, namely the idea of universal equality in education, which in the world is embodied from the middle of the $20^{\text {th }}$ century, and the result is the same - the emergence of the so-called academic proletariat (Calhoun 2011). Though its features and functions are different: in Ukraine, they are often "non-members of the families" of eminent scientists, that is why our version of the strata is similar to the one of the caste, but abroad - they are lower-class professors (mostly young or guests from less developed countries, or non-members of technological sciences), who significantly differ from known and respected or local professors as far as the salary or deference are concerned. This stratification extends to universities in general. When some universities become prestigious not because of their academic achievements (although the latter are difficult to 
measure, perhaps through the development of criteria for calculating the added educational value (Pawlowski 2005)), but thanks to their location in major cities (capitals) or leading positions in various ratings, the quality of their formation is usually poorly controlled, although actively advertised. In such a way, universities legitimize social inequality, which is in conflict with their original goal/idea.

Socio-class university identification, the causes and consequences of which very clearly point out that more scientific and public attention should be paid to its content, is held according to the mechanism, which was described by W. Sumner in his Folkways (1906). It is dedicated to the concept of ethnocentrism, and the author, analyzing the susceptibility of groups or individuals, either evaluates or accepts different social phenomena, depending on the value and ideas of their ethnic group and the developed concepts of "we-group" ("in-group", "we-group") and "they-group" ("out-groups", "other-groups"), through social relationships and fixed directives (the issue of value). According to Sumner, "we-group" is characterized by united and cohesive relations, and the relationship of these groups are tense and hostile (in the modern sense - competition, conflicts). It is worth noticing that the lower the level of social development of society, the more severe the opposition between these groups and the more regulated the relationship between them. So, firstly, the process of goal-setting is somehow taking place in a cultural and educational space of the university and secondly, certain orientation is formed depending on the real-life goals, thirdly, as a result of the above-mentioned, the level of performance of future professional activity is set and it is connected with an expected class (sometimes class or caste) division. This means that social and class self-identity of the university largely determines the future lives of its graduates, antecedently, bringing them to a certain level ("social elevator"). At the same time, the best possible strata options is to precisely target the university at a class which is the most dynamic, thus, the most relevant to the needs of modern social life strata, where the frames "in-" and "out-group" lose their significance because of the high level of social development.

The result of collective identification due to the cultural and educational space of pedagogical university, in addition to completed identity, is also a proper identity policy both as a theoretical concept, and as a social practice. The key feature of the latter is "its subjectivity as the ability of social actors to an active change" (Arbenina, Sokurianska 2012, p. 29), while the theoretical concept is "a set of ideas and actions, which broadcast some content and meaning of identities and is offered by various social agents (social actors and institutions), who eagerly strive for recognition of identity data as legitimate" (ibid. p. 30). According to the interpretation of identity politics as a theoretical concept, it appears a translation of the content of patterns into educational values in cultural and educational space of the university. 
To sum up, identification, including self-identification processes that are actively taking place in cultural and educational space of modern universities, are, on the one hand, indicators of the development of subjectivity of universities, on the other - a prerequisite for the success of other functional subsystems of their cultural and educational space. The essence of the identification process is the university's cognition of a significant part of the content of similar and distinctive features of its own cultural and educational space. The research tasks are related to the internal organization of "I" of the universities, they consist in learning of occurring processes and their mechanisms to study the background of influential factors concerning the effectiveness of university education, although these factors are not always obvious.

The general conclusion is that the educational values in all dimensions (personal, professional, and institutional) are the product of identification processes of cultural and educational space of the university. Therefore, one should monitor not only the declared objectives and processes of identification/self-identification, but also the features of their course, means of "interpenetration" of experience, both institutional and individual.

\section{REFERENCES}

Арбєніна, В.Л., Сокурянська, Л.Г. (ред.), 2012, Украӥнське студентство у поиуках ідентичності. Харків: ХНУ імені В.Н. Каразіна.

Брюховецький, В.С., В’ячеслав Брюховецький: Хотів би бути схожим на рибалку 3 повісті «Старий і море», http://tvi.ua/program/2013/07/31/homo_sapiens_ vid_31072013 [access: 23.03.2017].

Гертман, М., 2003, Стратегический менеджмент. Санкт-Петербург: Издательский Дом «Нева».

Дробижева, Л., 2007, Предисловие. In: Л. Дробижева, Е. Головаха (ред.), Национальногражданские идентичности и толерантность. Опыт России и Украины в период трансформации. Київ: Институт социологии НАН Украины.

Калхун, К., 2011, Потрібно ставити питання про мету існування університету. «Спільне: журнал соціальної критики», № 3.

Козловець, М.А., Захарченко, I.М., 2001, Референтні структури як чинник соціальної ідентибікації особистості. «Вісник Житомирського державного педагогічного університету», № 8 .

Павловський, К., 2005, Трансформації вищої освіти в ХХІ столітті: польський досвід. Київ.

Перминова, Л.М., 2004, Самоидентификаиия учителей: опыт дидактической реблексии. Санкт-Петербург: СПб АППО. 
Петровский, А.В., 1982, Личность. Деятельность. Коллектив. Москва: Політ.

Семенова, Ю.А., 2004, Тілесна самоідентифікація в умовах культурних трансформацій. Харків: Харківський національний ун-т ім. В.Н.Каразіна.

Симончук, Е., 2007, Классовые структуры в сравнительной перспективе. In: Е. Головаха, С. Макеев (ред.), Украинское общество в европейском пространстве. Київ: Институт социологии НАНУ.

Совсун, I.Р., 2011, Новий порядок денний для університетської освіти. «Спільне: журнал соціальної критики», № 3.

Степин, B.С., 2004, Наука. In: А.А. Ивин (ред.), Филособия. Энциклопедический словарь. Москва: «Гардарики».

Туркот, Т.I., 2011, Педагогіка вищої школи. Київ: Кондор.

Caffentzis, G., Federici, G., 2007, Notes on the Edu-Factory and Cognitive Capitalism, http:/eipcp.net/transversal/0809/caffentzisfederici/en [access: 20.03.2018].

Shulga, M.A., Negative Discourse of Identity: A European Dimension, http://politologua.io.ua/s423392/marina_shulga_negativniy_diskurs_identichnosti_evropeyskiy_vimir [access: 15.03.2018].

Sumner, W.G., 1906, Folkways. A Study of the Sociological, Importance of Usages, Manners, Customs, Mores, and Morals. Boston: The Athenaeum Press.

Wright, E.O., 1978, Class, Crisis, and the State. London: New Left Books.

\title{
PROCESY IDENTYFIKACYJNE W PRZESTRZENI KULTUROWO-HISTORYCZNEJ UNIWERSYTETU JAKO ŹRÓDŁO POWSTANIA WARTOŚCI EDUKACYJNYCH
}

\begin{abstract}
Abstrakt: Wartości, szczególnie edukacyjne są promowane przez instytucje dlatego badanie ich treści bez uwzględnienia analizy środowiska instytucyjnego powoduje fragmentaryczność badania. W uniwersytecie, w jego przestrzeni kulturowo-historycznej, wartości nie tylko powstają, rozwijają się, stabilizują, ale także korelują z obowiązującym statusem politycznym, gospodarczym, socjalnym. Proces generowania wartości zachodzi równolegle z procesem identyfikacji, w efekcie czego różne grupy wartości tworzą odmienne warianty identyfikacji określające rodzaj uniwersytetu i jego główne cechy zwłaszcza cechy własne. Może to być identyfikacja czasowa, cielesna, socjalno-klasowa; można też omawiać identyfikację płciową, narodową itp., prezentowane w rzeczywistości ukraińskiej.
\end{abstract}

Słowa kluczowe: uniwersytet, przestrzeń kulturowo-edukacyjna, identyfikacja, samoidentyfikacja, wartości 